DOI: $10.31548 /$ machenergy.2020.01.105-113

UDC 662.71 .74

\title{
RESEARCH OF ADVANCED CRUSHER WOOD BIOMASS FOR SOLID FUEL PRODUCTION
}

\section{O. I. Yeremenko}

National University of Life and Environmental Sciences of Ukraine. Ukraine.

Speciality of article: 162 - biotechnology and bioengineering.

Corresponding author: eremolex@ukr.net

Article history: Received - October 2019, Accepted - January 2020.

Bibl. 13, fig. 4, tabl. 0.

Abstract. The work deals with the crushing of recycled wood biomass for the production of pellets or briquettes to justify structurally-technological scheme and parameters of perspective crusher. The identified prospects solid biofuel production in terms of economy Analysis processes and designs devices for crushing biomass. Your rational type Hammer crusher without reshitnoyi for use in industrial complexes economy.

Analytical studies demonstrated the feasibility of ram hammer crusher sieveless DMB-F (0.5-1.5) for crushing to pressing wood biomass in fuel products. The functional scheme of technical means, carried out engineering calculations modes and parameters of the crusher. The obtained results show the efficiency of the process of crushing raw wood at that mill.

Key words: processes of grinding, wood biomass, solid biofuels, working bodies, crusher sieveless, calculations, parameters.

\section{Introduction}

Due to exhaustion and environmental harmfulness of traditional fossil energy sources, including natural gas, oil, coal, increasing significance acquires alternative energy, including biofuels. For the production of solid biofuels using waste wood and logging, agricultural byproducts and processing enterprises, energy crops. Artificial Fuel wood is produced by pelleting or briquetting materials prepared in the respective pressing machines under the pressure of 10 to $40 \mathrm{MPa}$.

\section{Formulation of problem}

Preparation of solid production processes involve removal of moisture from wood biomass to $10-14 \%$ and the final crushing of the state of sawdust with particle sizes of 1-5 mm [1-3]. This degree will provide the crushing hammer and rotary crushers and disintegrants [4].

Features of the physical and mechanical properties of wood raw material and process manufacturing solid products provide depth study of fine grinding and rational justification type crusher.

\section{Analysis of recent research results}

The process of grinding technology is the destruction of the material under external driving forces. Depending on the size of the final product distinguish a class crushing hard materials, crushing-large $(100-350 \mathrm{~mm})$, medium (40-100 $\mathrm{mm})$ and small $(5-40 \mathrm{~mm})$, coarse grinding (particle $0.1-5 \mathrm{~mm})$ and thin $(0.05-0.1 \mathrm{~mm})$ ultra-thin $(<0.05 \mathrm{~mm})[1,5,6]$

The main characteristic of the process is the degree of grinding, which is defined by the weighted average particle size of the material before and after grinding [7] and $=d o / d k$. The process of chopping wood for the production of pellets or briquettes carried out sequentially in several stages with the transition from coarse crushing to grinding [1, 3, 8-10].

Energy costs and the burden on the working bodies of the crushed material and quality depend on the strength, brittleness, hardness, elasticity, density of wood materials.

Strength -property of wood to resist destruction in the event of internal pressure during exercise. Strength is measured strength $\sigma \mathrm{s}$ limit. Wood materials are divided into soft $(\sigma \mathrm{s}<80 \mathrm{MPa})$, medium $(\sigma \mathrm{s}=80-150 \mathrm{MPa})$, strong $(\sigma s=150-250 \mathrm{MPa})[10,11]$.

The fragility of a property collapse without noticeable wood plastic deformation is determined on the number of strokes copra dimensional cargo. According to the number of blows to withstand designs, materials share a very fragile (2), fragile (2-5), structures (5-10) [10, 11].

Choose how chopping wood depends on the physical and mechanical properties of the material. Solid wood species, such as yew, acacia, oak, beech advisable to grind blow, splitting or friction. Soft, more viscous trees, such as spruce and other conifers, poplar, willow, aspen better way to grind cutting. Grinding of trees often perform shocks and abrasion [1, 4, 6, 10-12].

Theory wood grinding process provides the link between energy consumption and final particle size, physical and mechanical properties and so on. According to P. Rittynhera hypothesis $[12,13]$ work $(\mathrm{J})$ during the grinding wood biomass is proportional to the square newly formed surface: $A \Delta F$

$$
A=K_{1} \Delta F,
$$

where $K_{1}$ - coefficient of proportionality. 
The value can be expressed in the initial and final size of wood particles. Assuming that the particles have the shape of a cube with edges to grinding and after grinding, the surface of the material is given by $\Delta F d_{\text {п }} d_{\mathrm{\kappa}} d_{\Pi} d_{\mathrm{\kappa}}=d_{\text {п }} / i[12,14]$ :

$$
\Delta F=F_{\mathrm{\kappa}}-F_{\Pi}=6 i^{3}\left(\frac{d_{\Pi}}{i}\right)^{2}-6 d_{\Pi}^{2}=6 d_{\Pi}^{2}(i-1),
$$

When grinding the material volume $\left(\mathrm{m}_{3}\right)$ with particle sizes equal to the total number of particles, and work in accordance with the formula (1) defined [12]: $V d_{\Pi} V / d_{\Pi}{ }^{3}$

$$
A=6 K_{1} V(i-1) / d_{\Pi}
$$

According to other studies [15] while chopping wood crushing weight of the total number of particles is then determined in accordance with the work: $m_{\mathrm{M}} \frac{m_{\mathrm{M}}}{\rho d_{\Pi}{ }^{3}}$

$$
A=\frac{K_{2} m_{\mathrm{M}}}{\rho} \text {. }
$$

In reality, chopping wood materials is a complex process. Theory of the formula (1) does not include the costs of elastic deformation. Therefore, this formula is used to describe the process of fine crushing and grinding of wood biomass. Calculations using formula (3) to evaluate the deformation energy, but do not include the cost of the formation of new surfaces. This formula is advisable to apply at large and medium crushing when little impact surfaces.

In fact, during the grinding of wood particles and deformation effects the formation of new surfaces occur simultaneously. So many publications [12, 16-19] describe these phenomena together. Based on the analysis offered empirical formula for the calculation of consumer power (kW) shredders $N[12,17,18]$ :

$$
N=0,13 E_{i} K_{\mathrm{M}} Q_{\mathrm{M}}(\sqrt{i}-1) / \sqrt{ } d_{\mathrm{\Pi}},
$$

where $E_{i}$ - the power indicator, depending on the physical and mechanical properties of wood, $K_{\mathrm{M}}$ - coefficient scale factor, $Q_{\mathrm{M}}$ capacity crusher, $\mathrm{kg} / \mathrm{s}$.

In the production of solid biofuels fine crushing and coarse grinding to a particle size of 1-5 mm materials often carry a percussion machine. Moving working bodies deform and destroy the material by the great speed of $1500 \mathrm{rev} / \mathrm{min}$., And particle collisions with stationary surfaces chambers. By shredders include percussion and rotary hammer mills and shredders finger [12, 14, 15].

These crushers are used for crushing trees of any viscosity and hardness. These machines provide a high degree of grinding: $=15-20$ and even up to $i=50$, which reduces the number of stages of crushing. Crushing material is subjected to mechanical shock. The kinetic energy of the working rotating partially or completely converted into deformation destruction [4, 12, 14, 15, 19].

Rotary cutters with rigid bylamy used for splitting wood pieces. Shvydkoobertovyy rotor creates a massive reserve of potential energy working bodies. In the hammer crusher with hammers pivotally suspended crushing process defines only the kinetic energy of the hammers themselves. Sizes rotor hammer crushers and set the length and diameter of the rotor disk $[12,14,15]$.

Hammer crusher (Fig. 1) in solid industries are widely used for fine crushing $(5-40 \mathrm{~mm})$ and grinding the raw biomass to a particle size $0.1-5 \mathrm{~mm}[1,3,5,6,12$, 14]. Crusher rotor shaft drives is 7 , which is pivotally mounted hammers 6 . The other bodies are working deck edge 2 and a sieve (sieve) 4. Particles of wood bioamsy destroyed by blows of hammers 6 and reflections on deck 2 and 4. shredding sieve particles pass through a perforated surface 4 to 5 device.

The control unit 3 is changing the gap between the hammers 6 and 2 deck Shvydkoobertovyy rotor forming in the exhaust device 5 excessive air pressure that promotes the release of chopped biomass. Fractional composition cleavage products depends on the speed of the hammers 6 , the gap between the rotor and deck 2, 4 sieve size openings $[12,18]$.

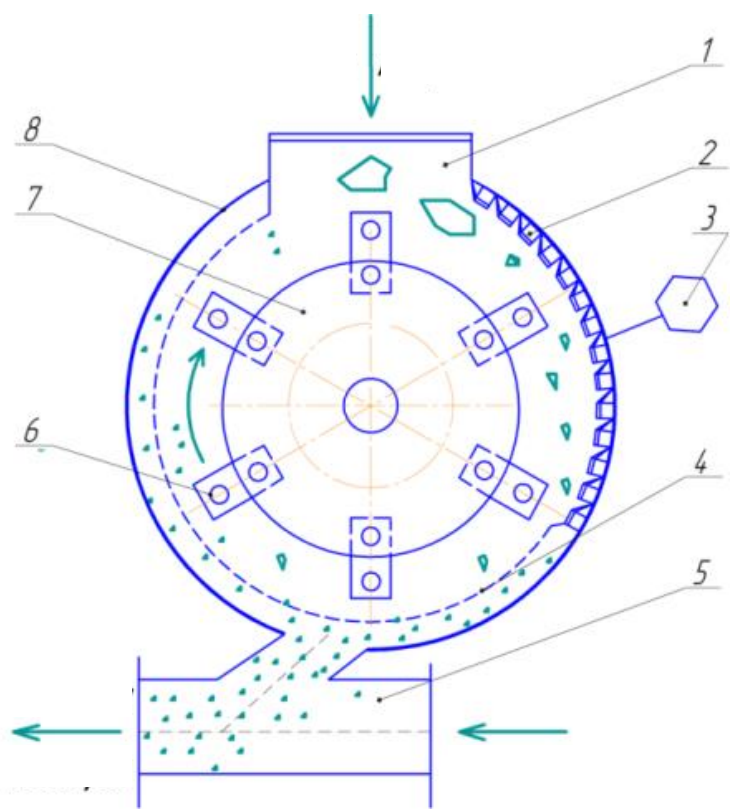

Fig. 1. Functional diagram of hammer crusher: 1 - receiver, 2 - deck edge, 3 - regulating device, 4 - sieve (sieve), 5 - discharge device, 6 - hammer, 7 - disc rotor, 8 - housing.

Enough speed particles of wood biomass for efficient crushing of about 2 deck edge is based on the theory of shock $v_{\mathrm{M}}[12,16-18]$

$$
P \tau=m v_{\mathrm{M}},
$$

where $P$ - destructive efforts carts of wood particles, $\tau$ - interaction term (impact) of the particle surface (10$5 \mathrm{~s}), \quad \tau \approx m$-mass particles crushed, - the speed of the material at the time of hitting the deck edge $v_{\mathrm{M}}$.

$$
v_{\mathrm{M}} \approx v_{\text {п }}-v_{\text {вит }} \text {, }
$$
where $v_{\text {п }}$ - the speed of air, $v_{\text {вит }}$ - speed particles greetings.

The process of chopping wood biomass as a hammer mill conventionally divided into two phases. In the first stage the material is destroyed hammer blows in the area of their rotation. The major importance velocity hammers, structural and mechanical properties of the material, the angle off meeting of the working surface of the material. Circumferential speed hammers to perform the process varies from 40-100 m/s, depending on the physical and mechanical properties, moisture content and status of hammers $[12,14,16,18]$.

The second phase of biomass particles are destroyed by repeated hammer blows and hitting the deck edge and friction particles on work surface. At this stage the main factors is the kinetic energy of the wood particles from the action of the workers, the number of hammers and charts their location, the gap between the hammers and deck, stay in the area of grinding material $[12,14,16,18]$. 
When worn hammers distance between their ends and the inner surface of the crushing chamber increases, not crushed material, the cost of energy to overcome friction increases. In addition, excessive and uneven wear of hammers broken rotor balancing, vibration occurs, which leads to polamok machine. Hammers crushers vyhotovlyuyut of high-alloy steels, including 30HGS, 65G-3 110H13L etc., reinforced with structural steel surface or carbon steel with wear-resistant welding alloys working surface. For grinding materials of different tree species are different forms of hammers. Design and implementation of reversible rotor increases twice resource crusher $[6,12,14,18,19,21]$.

In the process industry often used crusher with hammers in a plate with holes at the edges. The advantages of such bilateral hammers:

- with two holes 4 working surface used for crushing hammers, whereby reversal operation hammers do not carry through reverse drive,

- easy to manufacture, assembly and sharpening $[6$, 7, 12, 14, 18, 19].

Advantages of hammer mills lies in their versatility, the ability to grind many kinds of raw materials. Hammer mills have relatively small dimensions, high performance $[12,14,15,18]$.

For grinding plant material domestic industry produces a significant amount of hammer crusher sizes. It is worth noting several serieshammer type shredder for processing wood materials:

- Crusher size-HTDRM 0.7 / 55, produces a joint Italian-Ukrainian Engineering Group ICK Group TM GRANTECH (Grantekh) performance - up to $3 \mathrm{t} / \mathrm{h}$ designed for grinding feed and solid materials [2, 3, 18],

- Crusher Model DM-4 performance - $3 \mathrm{t} / \mathrm{h}$, designed for the final grinding chips and small lump of waste,

- Hammer mill MM-03a-C performance - $2 \mathrm{t} / \mathrm{h}$, designed for shredding wood shavings on the type DS machines,

- Hammer mill MK-10, capacity - $25 \mathrm{~m}^{3} / \mathrm{h}$ designed for shredding tree bark $[6,14,15]$.

The analysis of processes and structures shredder hammer wood materials indicates the presence of significant drawbacks of these facilities. Despite the high performance hammer reshitni (Screen) mills are increasing by $12-18 \%$ specific indicators of energy consumption compared to sieveless crusher.Hammer Crusher without grate grates provide uniform crushing of wood thanks to multiple percussion hammers for the passage through the mill wood biomass $[1,12,18]$.

The disadvantages of crushers sieve bottoms (grid) is attributed to rapid wear of hammers, pneumatic panels (rib dec) Pile arrays of holes in the grinding increased to $15 \%$ moisture content softwood trees, the complexity of installing and balancing the rotor. In the crushing material over $12-14 \%$ moisture pick plates are made, usually without reefs, because the reefs pressed wood milled material, which reduces the efficiency of crushing plate against $[1,12,14,18]$.

Grizzly grid (sieve) is from $80^{\circ}$ to $180^{\circ}$ range of the bottom of the rotor. The design must allow arrays to change their position relative to the rotor for adjusting the crusher for a given size of 1-5 mm crushed chips, as well as to compensate for the wear of hammers and the rib deck. In this regard lattice makes turning or lifting, but some designs are made stationary crushers, which is a significant drawback of crushers. [6, 12, 15, 18].

Disadvantages hammer crushers are also in a nonuniform dispersion of chopped biomass. Along with enough crushed raw material particles there are too crushed. Getting too crushed particles accompanied by energy. Because grinding often used a two-stage screening process with the use of crushed material. A large fraction returned to pre-crusher and crushed by the weight goes further technological purpose $[6,12,15$, 18, 19].

Thus, hammer crusher reshitni for operational and economic performance inferior sieveless ram hammer crusher small solid business conditions in the farms $[2,3$, $6,12,18]$.

So there is a need for more in-depth research and resolution of these issues reasonably rational choice type hammer crusher.

\section{Purpose of research}

Improved solid production in the economy through the study process, design parameters and fundamental perspective sieveless hammer crusher.

\section{Results of research}

To select promising type of hammer crusher for small solid-fuel production in farms Analytical review of processes and structures sieveless series of hammer crushers.

DB-5 Crusher Hammer sieveless (Fig. 2) is designed for grinding all types of dispersed materials [4, 17, 18].

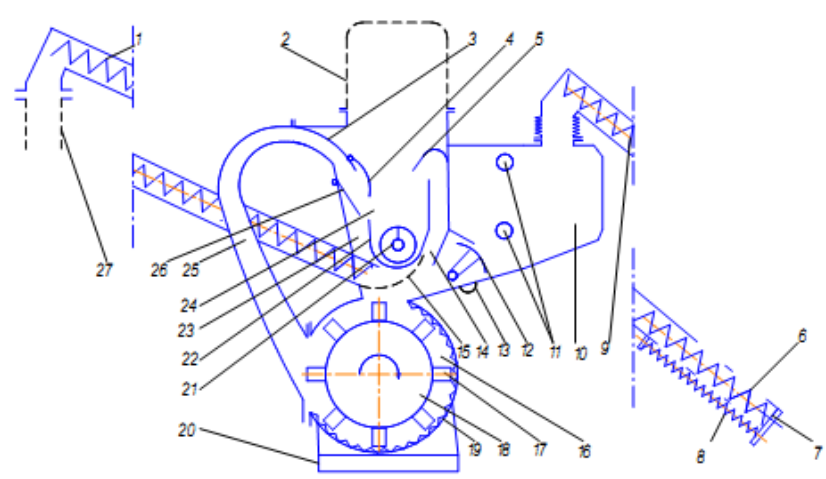

Fig. 2. Structural and technological scheme sieveless crusher DB-5, 1 - unloading conveyor, 2 - filter, 3 - directional peak crushed material, 4 - extension visor, 5 - peak airflow, 6 - reception window, 7 - drive screw, 8 - additional screw, 9 - loading conveyor, 10 - bunker, 11 - level sensors, 12 - valve supply, 13 - discharge separator, 14 - reverse feed air supply, 15 - lotik, 16 - grinding chamber, 17 - hammer, 18 - rotor, 19 - deck, 20 - frame, 21 - horizontal auger, 22 - horizontal auger trough, 23 - back channel not crushed material, 24 - resolution camera, 25 - air guidance, 26 - adjusting plate, 27 - fabric sleeve. 

discs.

The rotor 18 has a shaft on which a remote plugs are

On the periphery of the discs made eight holes, which are inserted into the axis of suspension. Axes pivotally suspended hammers 17 arranged via spacer sleeves.

Camera Resolution 24 is intended for separation of shredded particle size with the direction of the second stage of grinding coarse fraction.

Inside the chamber made two channels: the reverse channel 23 not crushed material that returns this faction in the grinding chamber and channel 14 for recirculation of air.

Resolution camera is connected to the grinding chamber pneumatic wire 25 . To avoid dead zones and avoiding cross-section pneumatic pneumatic wire constantly shrinking.

Continued outer curved surface air guidance is peak 3 , which moves minced raw materials.

To change a feedstock resolution camera has two regulation: curved flap 4 as extension visor 3 and adjusting plate 26 intended to regulate quality in grinding particulate humidity conditioning.

Crusher is so. Filed boot belt material is stored in a bunker and in a certain dosage amount enters the crushing chamber. Crushed with hammers and grooved dekamy particles discharged by pneumatic wire resolution in the camera. Feedback channel 23 is fully open plate 26 and the majority of the material along with part of the air enters the re-crushing. Small particles vidsiyuyutsya air flow through the window, fall to a horizontal auger and removed from the resolution of the camera. Additional peak air flow 5 is sent back to the camera shredding. It provides very fine grinding. When shifting plate 26 of the chamber wall right crack return channel 23 narrows the air out of the window increases, providing a more intense output of crushed material in the zone of the horizontal auger. As a result, the average particle size designated particles increases. At the far right of the plate 26 completely covers the back channel and the whole product comes to horizontal auger without separation.

The described process and structure of the crusher suggest a complex structure means reliability and low maintenance.

Crusher DMB-M (Fig. 3) is designed for grinding all kinds of bulk organic materials $[1,12,18]$. The process takes place in grinding mode ramjet in the chamber without the grate sieves (screens).

Crusher consists of a hopper 6, 7 metering device, camera, crushing hammer rotor with 8 horizontal cyclone 5 and drive. Camera grinding has two windows for loading and unloading material. At discharge box connected to the cyclone 5. The inner surface of the chamber are used corrugated Dec. 9, which differ between step keys and the distance to the hammers. During the movement of material in the cell gap decreases. Moving the outer decks made mechanism for regulating the degree of crushing channel 1 output of crushed material from the cyclone is made in the form of curl, and the axis of the cylinder and cyclone screw removed. Cyclone has two discharge neck with fabric sleeve, and on the opposite side of the loop connected to the grinding chamber pipe 3 for air circulation.
The analysis found that most existing sieveless hammer crushers have a complex structure, low operational reliability, high metal content, high cost. Therefore we think that the most favorable means for the crushing of wood biomass for the production of solid fuel in terms of economy will sieveless crusher model DMB-F $(0.5-1.5)$ with rotary hammer mechanism $[4,20]$.

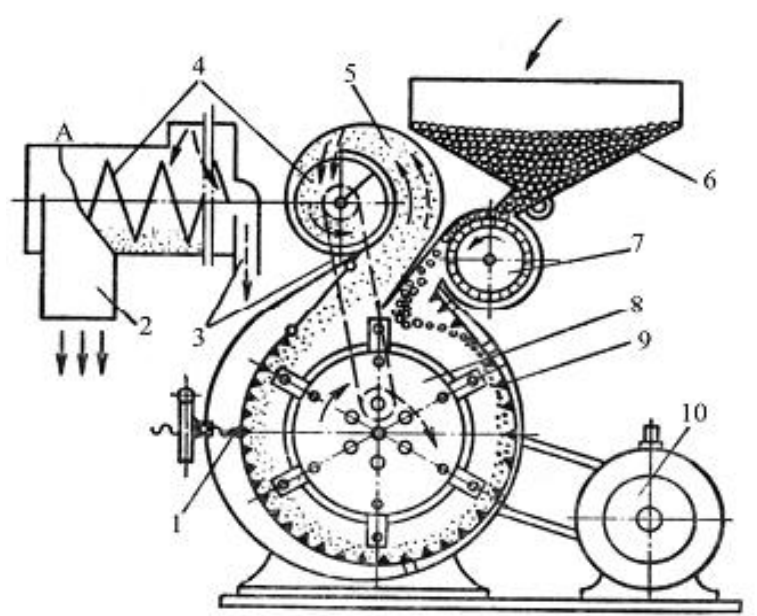

Fig. 3. Structural and technological scheme sieveless hammer crusher DMB-M: 1 - grinding degree adjustment mechanism, 2 - discharge hose, 3 - pipe for air circulation, 4 - unloading auger, 5 - cyclone, 6 - bunker, 7 - dispenser, 8 - hammer rotor, 9 - deck, 10 - motor

In its further investigation sieveless mill (Fig. 4) to break down woody biomass is subjected to mechanical shocks and hammers counterrib deck. The kinetic energy of moving particles of wood (chips, shavings) fully or partially transferred to the energy of deformation and destruction. As a result of the impact hammer wood material particles partially destroyed and discarded on the edge deck 3, creating a crushing chamber. Udaryayuchys about the deck, additional material is crushed and fighting again fall under the rotor 2 . This is repeated several times until the particles of material reaching a certain size do not come out of the grinding zone for unloading.

To realize the impact force necessary for breaking the wood material bulk material should be sufficient to create a reactive force of inertia, utakes on the force of impact. The minimum critical size of particles $(\mathrm{m})$ timber is determined by the formula [12] $d_{\mathrm{\kappa p}}$

$$
d_{\text {кр }}=230 \cdot 10^{-5} \sigma_{\mathrm{p}} /\left(\rho v_{\mathrm{p}}\right)^{1,5},
$$

where $\sigma_{\mathrm{p}}$ - tensile strength of the material in tension, $\mathrm{Pa}, \rho$ - density wood material $\mathrm{Kg} / \mathrm{m}^{3}, v_{\mathrm{p}}$ - circular rotor speed, $\mathrm{m} / \mathrm{s}$.

Required for the process circular rotor speed is defined as $[12,18]: v_{\mathrm{p}}$

$$
v_{\mathrm{p}}=1,75 \cdot 10^{-2} \sqrt[3]{\left[\sigma_{\mathrm{p}} /\left(\rho D_{\text {св }}\right)\right]^{2}} .
$$

In spivudari solid wood particles impact force depends on their weight, relative velocity impact, the physical and mechanical properties of wood materials and forms contact surfaces. In practice, often the intermediate state between elastic and inelastic visitors.

Based on the energy balance of the rotor and wood particles before and after the impact and results of 
experiments [18, 19], taking into account the actual conditions of the process, using the formula for calculating the energy splitting $\mathrm{E}_{\text {дроб }}[12,18]$ :

$$
\mathrm{E}_{\text {дроб }}=2 k_{1} m_{k} v_{\mathrm{p}}^{2} \text {, }
$$

where $k_{1}=0,9-0,95$ - coefficient taking into account the conditions of the process, $m_{\mathrm{K}}$ - the mass of wood pulp, $\mathrm{kg}$.
According to the theory of impact at spivudari rotor weight $m_{\mathrm{p}}$ wood and particle mass $m_{k}$ That much less weight rotor velocity in the direction of impact is almost zero. Thus, shock pulse at netsentrovomu hit by the formula $S[12,17,18]$ :

$$
S=m_{\mathrm{K}} v_{\mathrm{p}}\left(1+k_{\mathrm{B}}\right) /\left(1+\frac{e^{2}}{r^{2}}\right),
$$
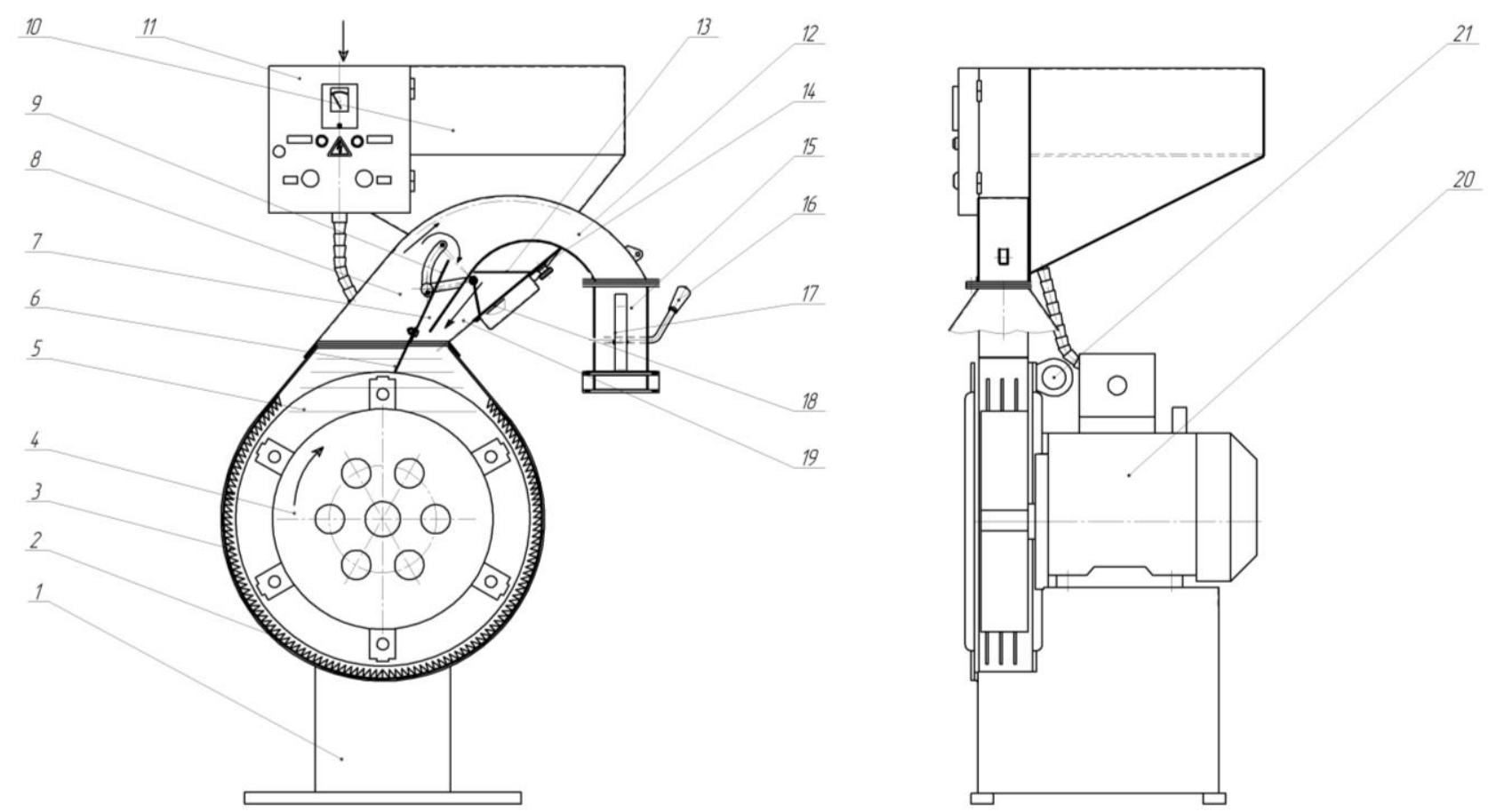

Fig. 4. Constructional and technological perspective diagram sieveless crusher DMB-F (0.5-1.5): 1 - frame, 2 - case, 3 - deck edge, 4 - rotor hammer, 5 - circular protrusions (smooth side deck) crushing chamber, 6 - valve for changing the direction of air flow and pressure, 7 - channel to closed loop air flow, 8 - discharge pipe, 9 - guide wall, 10 - bunker, 11 - control panel, 12 - unit loading and unloading, 13 - valve to change the supply of source material, 14 - magnetic trap, 15 - discharge socket, 16 - valve handle, 17 - device for attaching the container, 18 - pipe boot, 19 - channel for air leak, 20 - motor, 21 - bracket for slinging.

where $k_{\mathrm{B}}$ - recovery factor equal to the ratio of the relative velocity of the particles before and after impact, - eccentricity striking force relative to the center of mass particle $\mathrm{m}$, - radius of inertia of particle m.er

$$
\text { At } e=0, . S=m_{\mathrm{K}} v_{\mathrm{p}}\left(1+k_{\mathrm{B}}\right) \text {. }
$$

A default formula (11) made the assumption that the body, which are mutually bump, not destroyed. In the first phase the kinetic energy of the rotor effort goes into potential energy of elastic deformation. At this point wood particles acquire a speed equal to the speed of the rotor.

In the second phase of elastic deformation energy turns into kinetic energy of a particle. In this piece, starting from the hammer gets speed. Shot Power is reduced to zero. In reality, the particle is destroyed. This shock impulse rotor $(\mathrm{H} \cdot \mathrm{s})$ is given by $k_{\mathrm{B}} v_{\mathrm{p}} S_{\mathrm{p}}[12,17,18]$ :

$$
S_{\mathrm{p}}=\beta m_{\mathrm{\kappa}} v_{\mathrm{p}}\left(1+k_{\mathrm{B}}\right) \text {, }
$$

where $\beta=0.4-0.5$ - factor of active material.

When the rotor angular velocity of $20-40 \mathrm{~m} / \mathrm{s}$, the stroke is 0,001-0,008 with. The intervals between beats, when the rotor store energy, is much larger $0,012-0,024 \mathrm{sec}$. So, to strike only applies kinetic energy of the rotor $[12,17,18]$.
To make a crushing rotor should have a dynamic moment of inertia $J\left(\mathrm{~kg} \cdot \mathrm{m}^{2}\right)[12]$ :

$$
J=S_{\mathrm{p}} D_{\mathrm{p}} /\left(2 \omega_{\mathrm{H}} \delta\right)
$$

where $\omega_{\mathrm{H}^{-}}$rated angular speed of the rotor, $\mathrm{rad} / \mathrm{s}, 0,02-$ $0,03 . \delta=\left(\omega_{\max }-\omega_{\min }\right) / \omega_{\mathrm{H}}$ - the degree of uneven rotor.

Strike force $(\mathrm{N})$ can be determined by the formula $P_{\mathrm{y}}$ [12, 16-18]:

$$
P_{\mathrm{y}}=\frac{2 S_{\mathrm{p}}}{t_{\mathrm{y}}} \approx 400 S_{\mathrm{p}} v_{\mathrm{p}}^{0,5},
$$

where $t_{\mathrm{y}}$ - a blow with.

Strike force taking as a starting load to determine the forces acting on the rotor shaft and bearings.

Structural dimensions crushers determined depending on the size $d$ maximumparticles in the original wood biomass $[12,14,18]$. The diameter of the rotor for vertical load crushers $D_{\mathrm{p}}=3 d+550$ length of the rotor $L_{\mathrm{p}}=(0,8-1,2) D_{\mathrm{p}}$.

Length off the axis of suspension to the outer edge advisable to be equal. $[12,14,18]$ The shape and size of hammers must provide the maximum possible discharge axis of suspension upon impact $(0,2-0,25) D_{\mathrm{p}}$. 
To ensure the efficiency and reliability of the process sieveless ram crusher established [16, 17] that the length of the stream woody biomass should be equal to the length of the working surface of the crushing chamber. The ratio of each specified length to its radius and angular velocity and attitude at the ends of the hammers to the average angular velocity of flow and should make the same constant value equal to 5 at the optimum operating condition. Due to technical difficulties and design to create a continuous and uniform flow in the working range of the crushing chamber, taking the average radius of the flows of mass equal to the radius of the rotor $l_{k} L_{\mathrm{P}} R_{k} R_{\mathrm{p}} R_{k} R_{\mathrm{p}}$.

To provide standard conditions for the particle size for crushing ram sieveless Hammer crusher is necessary to determine optimal crushing chamber width based performance. Established $[16,17]$ that the performance of these mills is proportional to the width of the crushing chamber. This optimal crushing chamber width is $50 \mathrm{~mm}$ per 1 ton per hour performance that expresses the relative width of the crushing chamber $(\mathrm{m} \cdot \mathrm{s} / \mathrm{kg})$ of the formula $B_{k}[16,17]$ :

$$
b_{k}=\frac{B_{k}}{m_{t}}
$$

where $m_{t}$ - the capacity of the crusher, $\mathrm{kg} / \mathrm{s}$.

From formula (15) we have

or

$$
B_{k}=m_{t} b_{k}
$$

$$
m_{t}=\frac{B_{k}}{b_{k}}
$$

According to the formula (15) relative width of the crushing chamber is $=0.18 \mathrm{~m} \cdot \mathrm{s} / \mathrm{kg}$. According to the formula (16), setting the capacity crusher can determine the width of crushing chamber and vice versa, using the formula (17), setting the width of the crushing chamber can determine throughput (productivity) crusher $b_{k}$.

To ensure the necessary size crushing, with reference to the hardness of the wood physical and mechanical properties, the minimum speed at the ends of circular hammer crushers ramjet sieveless must be at least $60 \mathrm{~m} /$ s. Established [16, 17, 18] that the minimum radius of the rotor should be $0.2 \mathrm{~m}$ at a frequency of rotation of at least 2800-3000 rev / min.

For any size [20] sieveless ram hammer crusher hammer rotor with a radius within $0.2-0.3 \mathrm{~m}$ and the optimal operation mode crusher average circular flow rate of the working masses on average 5 times lower than the rate on the circular ends hammers. This decrease in the average angular velocity stream of woody biomass is due to a significant slowdown flow rib deck crushing chamber. This increases the number and intensity of hammer blows on the wooden mass, which enables the achievement of the required grinding size in one pass through the crushing weight of the working chamber.

Number of hammer blows on the wooden mass depends on the amount of braking rotor speed, the number of hammers on the rotor and hammers travel time length of the working surface crushing chamber. Thus for sieveless hammer crushers derived formula $[16,18,20]$ that for determining the number of hammer blows on wood biomass, are as follows $K_{\text {уд }}$ :

$$
K_{\text {уд }}=\frac{V_{\mathrm{M}} n_{\mathrm{M}}}{V_{\mathrm{cp}} 60} Z_{\mathrm{M}} \tau_{\mathrm{M}} \text {. }
$$

These provisions are methodological basis for calculation of parameters and compact design ram hammer crusher sieveless DMB-F (0.5-1.5). The purpose of this machine is fine crushing and milling to the size of 1-5 mm of all kinds of material discrete conditioning and high humidity $(12-30 \%)$ [16-18, 20]. Crusher can be used in farms or forests composed of complex technological equipment for manufacturing solid types of biofuels (pellets or briquettes) with logging, woodworking, agricultural and processing of waste.

The base model compact modification Hammer crusher sieveless DMB-F (0.5-1.5) consists of the main parts are indicated in Fig. 4. The feature of the crusher is that the frame design provides possibility to install it on different sizes of electric capacity $4.0,5.5$ or $7.5 \mathrm{~kW}$ under a given module performance: $0.8,1.1,1.5 \mathrm{t} / \mathrm{h}$ [1618, 20]. And Hammer rotor is mounted directly on the motor shaft. Crushing chamber volume is $67 \mathrm{dm} 3$ capacity of $45-50 \mathrm{~kg}$ wood materials soft rock and other bulk materials.

The process crusher DMB-F (0.5-1.5) is carried out in a manner $[17,18,20]$. After the crusher in idle mode opens adjusting valve 13 (see. Fig. 4). Wood raw materials (wood chips, shavings etc.) with a humidity of $10-15 \%$ under the force of its own gravity passes control magnetic trap 14 and enters a uniform flow in the feed pipe 18. However, bulk raw wood cutters in the crushing chamber rapidly comes from the outside air through the channel to leak air 19. This phenomenon is due to the work of the hammer rotor 4 mode fan. As a result of mixing wood biomass with air is formed on the mixture, which promotes uniformity of input raw material crushing chamber in concurrent flow in the direction of rotation of the rotor 4.

Under the influence of hammer blows in the form of wood particles obtained kinetic energy that creates tension strain in the particles. At the same time, the particles acquire a circumferential speed of $50 \mathrm{~s}-1$ rotor. In the next moment after receiving hammer blows most wood particles strikes against the rib deck 3 is partially destroyed and partially lose speed, which is reduced by about five times the speed of the rotor. In addition, the particles being in the state of stress from impact hammers and soundboard 3, facing each other and break up too. Loop statements (smooth side deck) 5 crushing chamber restricting the flow along the sides and contribute to its uniformity.

The process is repeated crushing to the output of processed wood biomass crushing chamber. In the tube 8 chopped wood material continues its movement and in addition partially stratified, namely heavier and less grinding particles are concentrated in the lower layers of the stream, but rather crushed material is moved to the top of the pipe 8. After passing through the wall of the guide 9 , which is regulated, biomass lower layers to enter the channel closed-loop airflow 7 and returned to re-grinding, while the bulk goes to the discharge device 12 and then discharge into the socket with rocker valve $15 \mathrm{~m}$, which is distributed through the handle 16 in sack or other container.

Areas for further research workflows and compact design sieveless crusher DMB-F (0.5-1.5) for its improvement are: 
- the face of the hammers perform zigzag in a speech height of 5-7 $\mathrm{mm}$ length $20 \mathrm{~mm}$ symmetrical arrangement. This will increase to $15 \%$ intensity splitting wood biomass by increasing the number of strokes fibrous wood particles much angular face of the hammer,

- the edges of the deck 3 (see. Fig. 4) of the input half crushing chamber to perform with a slope of about 20 degrees to the direction of rotation of the rotor 4 . Alternatively, ribs initial half deck crushing chamber to perform with an inclination of 20 degrees in the direction of rotation of the rotor. This modification increases the degree of fragmentation of large particles of biomass input half of crushing chamber and ensure uniform flow of crushed biomass in the initial half of crushing chamber,

- discharge funnel 15 (see. Fig. 4) to perform as two nozzles instead of one to ensure continuous sequential release of chopped wood pulp with a corresponding flow switching valve rocker 16 .

\section{Conclusions}

1. The analysis of the essence of the phenomenon chopping wood biomass as simultaneous destruction of the material and the formation of new surfaces. To make pellet or briquette pressing to manufacture solid biomass raw particle size must not exceed $4 \mathrm{~mm}$. According to the classification process is grinding rough grinding to size 0.1-5 mm. Such grinding provides rotary hammer, cone, buccal, pins (disintegrants), roller crusher.

2. Crushing blow hammer crusher provides a greater effect of grinding, crushing crushing than other types of crushers, such as buccal, or roller cone. The degree of grinding in the hammer crusher is 20-30, and the specific energy consumption for crushing at $18-25 \%$ lower than other crushers. Hammer mills more efficient, cost per unit of performance 2-5 times lower than the buccal and roll crushers, shredders and hammer of materials in 1,4-3 times less.

3. The process of chopping wood biomass by a blow to the hammer mill conventionally divided into two phases. In the first phase hammer blow kinetic energy of the rotor goes into potential energy of elastic deformation. At this moment all the wood particles gain speed rotor. In the second phase of elastic deformation energy turns into kinetic energy of a particle. In this piece, starting off from the rotor receives a certain speed. Shot Power is reduced to zero. In reality, the vast number of particles of biomass is destroyed.

4. Comparative analysis reshitnyh hammer (Seth) and sieveless crushers indicates that the crushing chamber reshitnyh crushers significant portion of the stream woody biomass tends to re-crushing. As a result, circulation is formed in the crushing chamber, resulting in increased energy intensity, metal, operating costs, difficult maintenance. As a result of the circulation of wood biomass in the crushing chamber reshitnyh crushers their performance significantly decreased to $18 \%$ compared to sieveless hammer crusher. Thus, the process of grinding in the hammer crusher reshitnyh needs improvement. Significantly increased more than $5.7 \%$ efficiency and reliability of the process in reshitnyh hammer crusher problematic compared with the same type ram sieveless crusher.

5. Technological advantages sieveless hammer crusher compared to reshitnymy (sieve) is that their design allows for the following:

- dismantle of the crushing chamber so inefficient and technologically unreliable knot, as sieve (strainer),

- eliminate circulation circle grind wood biomass and allow the grinding material in crusher chamber to ram cycle (without sieves),

- direct primary raw wood at the entrance to the crushing chamber during a collision counter it with hammers,

- change particle size crushing of wood and take samples without stopping the manufacturing process crusher,

- reduce the angular velocity grind wood biomass by approximately 5 orders of rotor rotation speed and thus increase the degree of crushing of raw materials,

- to implement closed loop dust-air mixture by using air flow generated by the rotor hammer.

6. The most favorable means for the crushing of wood biomass for the production of solid fuel in terms of economy is the smallest sieveless ram crusher brand DMB-F (0.5-1.5) with rotary hammer mechanism and the deck edge.

Splitting wood biomass in the mill is under the influence of mechanical shock. Thus the kinetic energy of the working bodies - hammers partially or completely converted into deformation damage.

Based on the analysis of the phenomenon by the crushing blow of wood materials shvydkoobertovymy of $1500 \mathrm{rpm} / \mathrm{min}$ working bodies determined that during rotation at impact hammers wood particles pass kinetic energy, which causes stress and deformation structures in themselves particles (Phase I). In the next moment due to the elastic properties of the particles gain speed in the passing flow that exceeds the circumferential speed hammer rotor (Phase II).

The process of fragmentation can occur in two ways. 1. The internal stresses in the particles exceeds the strength of the material instantly cracks and body collapses. 2. The value of voltage does not exceed the strength of wood particles and complete destruction missing. Formed only cracks at the next steps hammers or decks or in mutual collision of particles leading to their fragmentation.

7. Structural size of hammer crusher is determined based on the largest particle size wood material entering the mill. The diameter of the rotor for vertical load of the crushers, the length of the rotor. Length off the axis of suspension to the outer edge is assumed to be. The shape and size of hammers should ensure maximum possible discharge axis of suspension when struck by wood biomass $\quad d D_{\mathrm{p}}=3 d+550 L_{\mathrm{p}}=(0,8-1,2) D_{\mathrm{p}}(0,2-$ $0,25) D_{\mathrm{p}}$.

\section{References}

1. Polishchuk, V., Naumenko, V, Naumenko, $O$. (2018). Justification of capacity of the pellets granulation line at private enterprise "Malyn furniture factory". Teka commission of motorization and power industry in 
agriculture. 18(1). 7-16.

2. Golovkov, S. I., Koperin, I. F., Naydenov, B. F. (1987). Energeticheskoe ispolzovanie drevesnyh othodov [Energy use of wood waste]. Moscow: Forest Industry, 224.

3. Naydenov, B. F. (1971). Volumetric weights and specific volumes of goods: reference book. Moscow: Transport. 160.

4. Geletukha, G. (2015). Preparation and implementation of natural gas biomass substitution projects for the production of heat energy in Ukraine. Kyiv: Polygraph Plus. 72.

5. Collection of methods for calculating waste generation volumes. St. Petersburg: CECEC. 77.

6. Complex RK 847. ARIESUS UKRAINE. Available at: http://arjes.com.ua/production/kompleks-rk-847.html.

7. RM 41 chipper. ARIESUS UKRAINE. Available at: http://arjes.com.ua/production/rubalna-mashyna-rm41.html.

8. Sieve drum for sieving, calibration of different factions. all.biz. Available at: https://ua.all.biz/sitobarabanne-dlya-prosyuvannya-shchepi-g15731079.

9. Hammer crushers RM 71. ARIESUS UKRAINE. Available at: http://arjes.com.ua/production/molotkovyjpodribnjuvach-rm-71.html.

10. Dubrovin, V. O., Polishchuk, V. M., Tarasenko, S. E., Dragnev, S. V. (2013). Workshop on machinery and equipment for bioenergy. Kyiv. Agrar Media Group. 208.

11. Polishchuk, V. M., Dubrovin, V. O., Dragnev, S. V. (2013). Engineering systems of nature management. Part 2. Structural and technological calculation of granulator with a round matrix for the production of granulated biofuels: methodical instructions for the implementation of laboratory works. 48.

12. Polishchuk, V. M., Tarasenko, S. E. (2017). Biofuels. Production and use. 376.

13. Polishchuk, V. M., Tarasenko, S. E. (2016). Machines and equipment of bioenergy. Part 2. Structural and technological calculation of granulator with a round matrix in the line of production of fuel pellets: methodical instructions for the implementation of laboratory works. 34.

\section{Список літератури}

1. Polishchuk V., Naumenko $V$, Naumenko $O$. Justification of capacity of the pellets granulation line at private enterprise "Malyn furniture factory". Teka commission of motorization and power industry in agriculture. 2018. Vol. 18, № 1. P. 7-16.

2. Головков С. И., Коперин И. Ф., Найденов Б. Ф. Энергетическое использование древесных отходов. М.: Лесн. пром-сть, 1987. 224 с.

3. Найденов Б. Ф. Объемные веса и удельные объемы грузов: справочник. Москва. Транспорт, 1971. $160 \mathrm{c}$.

4. Підготовка та впровадження проектів заміщення природного газу біомасою при виробництві теплової енергії в Україні. За ред. Г. Гелетухи. Київ. Поліграф плюс, 2015. 72 с.

5. Сборник методик по расчету объемов образования отходов. Санкт-Петербург. ЦОЭК, 2004.
$77 \mathrm{c}$.

6. Комплекс RK 847. Матеріали из сайту АРIЄC УКРАÏHA. URL: http://arjes.com.ua/production/ kompleks-rk-847.html (дата доступу: 18.06.2018).

7. Рубальна машина RM 41. Матеріали из сайту APICC УКРАЇНА [Електронний ресурс]. URL: http://arjes.com.ua/production/rubalna-mashyna-rm41.html (дата доступу: 18.06.2018).

8. Сито барабанне для просіювання щепи, калібрування різних фракцій. Матеріали из сайту all.biz [Електронний pecypc]. URL: https://ua.all.biz/sito-barabanne-dlya-prosyuvannyashchepi-g15731079 (дата доступу: 18.06.2018).

9. Молотковий подрібнювач RM 71. Матеріали из сайту APIЄC УКРАЇНА [Електронний ресурс]. URL: http://arjes.com.ua/production/molotkovyj-podribnjuvachrm-71.html (дата доступу: 18.06.2018).

10. Дубровін В. О., Полішук В. М., Тарасенко С. С., Драгнєв С. В. Практикум з машин та обладнання для біоенергетики. Київ. АграрМедіаГруп, 2013. 208 с.

11. Полішук В. М., Дубровін В. О., Драгнєв С. В. Інженерія систем природокористування. Ч. 2. Конструктивно-технологічний розрахунок гранулятора 3 круглою матрицею для виробництва гранульованого біопалива. Київ. АграрМедіаГруп, 2013. 48 c.

12. Полішук В. М., Тарасенко С. С. Біопалива. Виробництво i використання. Київ. ЦП "КОМПРИНТ". 2017. 376 с.

13. Полімук В. М., Тарасенко С. С. Машини та обладнання біоенергетики. Ч. 2. Конструктивнотехнологічний розрахунок гранулятора 3 круглою матрицею в лінії виробництва паливних гранул. Київ. НУБіП України, 2016. 34 с.

\section{ДОСЛІДЖЕННЯ ПЕРСПЕКТИВНОЇ ДРОБАРКИ ДЕРЕВНОЇ БІОМАСИ ДЛЯ ТВЕРДОПАЛИВНОГО ВИРОБНИЦТВА \\ O. I. Сременко}

Анотація. Робота присвячена дослідженню процесів подрібнення вторинної деревної біомаси для виробництва пелет або брикетів 3 метою обгрунтування конструкційно-технологічної схеми і параметрів перспективної дробарки.

Визначено перспективи виробництва твердого біопалива в умовах господарства Проведено аналіз процесів і конструкцій пристроїв для подрібнення біомаси. Обрано раціональний тип молотковій без решітної дробарки для застосування в технологічних комплексах господарства.

Аналітичними дослідженнями доведено доцільність застосування прямоточної молотковій безрешітної дробарки ДМБ-Ф $(0,5-1,5)$ на дробленні деревної біомаси перед пресуванням в паливні вироби. Розроблено функціональну схему технічного засобу, проведені інженерні розрахунки режимів роботи і параметрів дробарки. Отримані результати свідчать про підвищення ефективності технологічного процесу дроблення деревної сировини на цій дробарці. 
Ключові слова: процеси подрібнення, деревна біомаса, тверді біопалива, робочі органи, безрешітна дробарка, розрахунки, параметри.

\section{ИССЛЕДОВАНИЕ ПЕРСПЕКТИВНОЙ ДРОБИЛКИ ДРЕВЕСНОЙ БИОМАССЫ ДЛЯ ТВЕРДОТОПЛИВНОГО ПРОИЗВОДСТВА \\ О. И. Еременко}

Аннотация. Работа посвящена исследованию процессов измельчения вторичной древесной биомассы для производства пеллет или брикетов с целью обоснования конструкционно-технологической схемы и параметров перспективной дробилки.

Определены перспективы производства твердого биотоплива в условиях хозяйства Проведен анализ процессов и конструкций устройств для измельчения биомассы. Выбран рациональный тип молотковой без решітної дробилки для применения в технологических комплексах хозяйства.

Аналитическими исследованиями доказана целесообразность применения прямоточної молотковой безрешітної дробилки ДМБ-Ф $(0,5-1,5)$ на дроблении древесной биомассы перед прессованием в топливные изделия. Разработана функциональная схема технического средства, проведены инженерные расчеты режимов работы и параметров дробилки. Полученные результаты свидетельствуют о повышении эффективности технологического процесса дробления древесного сырья на этой дробилке.

Ключевые слова: процессы измельчения, древесная биомасса, твердые биотоплива, рабочие органы, дробилка безрешетная, расчеты, параметры.

O. I. Yeremenko ORCID 0000-0003-0049-7224. 
